\title{
Citrus Nursery Production Guide, Chapter 8: Stock Plant and Tree Production: c) Weed Management in Citrus Nurseries ${ }^{1}$
}

\author{
Biwek Gairhe, Ramdas Kanissery, and Brent Sellers²
}

\section{Introduction}

Raising citrus trees in greenhouse nurseries is an important step in establishing a grove. All nursery operations should be directed toward the production of well-developed, healthy, and vigorous seedlings that can grow and thrive in field conditions. Florida state regulations require all citrus nursery stock, including seedlings, trees, and budwood, be raised in enclosed greenhouses separated from field citrus trees (Bureau of Citrus Budwood Registration 2014).

Weed infestation in greenhouse nurseries is considered less severe in comparison with field-grown nursery operations because of the controlled conditions. However, producing a weed-free citrus nursery stock is often a challenge to nursery growers. Even with the use of soilless growth media, weeds commonly occur in containers. The source of the potting mix can greatly impact the presence of future weed problems. Young citrus seedlings are especially susceptible to weed competition and can suffer direct damage, resulting in reduced vigor and growth.
Weeds readily germinate along edges of torn and worn areas of weed block fabric. The use of mulches such as fabric or gravel can help reduce weed germination in greenhouses, but crop debris and growing media can fill the spaces and negate their initial benefits. Weeds in walkways or under benches may not directly impact plant growth, but they do harbor pests (aphids, whiteflies, thrips, and mites) as well as diseases (Marble and Pickens 2015). Additionally, weeds may act as physical barriers to activities such as crop protection applications and pruning and budding operations.

\section{Common Weeds in Citrus Nurseries}

The following weeds are commonly found inside greenhouses and enclosed structures in Florida citrus nurseries. These weeds reproduce primarily by seed, with several generations occurring per year.

Creeping wood sorrel (Oxalis corniculata): A broadleaved, herbaceous, annual or perennial plant that reproduces through seed or vegetative propagation. It has a narrow, creeping stem, and its trifoliate leaves are subdivided into three rounded leaflets resembling a clover in shape. Seeds

1. This document is HS1344, one of a series of the Horticultural Sciences Department, UF/IFAS Extension. Original publication date October 2019. Visit the EDIS website at https://edis.ifas.ufl.edu for the currently supported version of this publication.

2. Biwek Gairhe, graduate student; Ramdas Kanissery, assistant professor, Horticultural Sciences Department, UF/IFAS Southwest Florida Research and Education Center; and Brent Sellers, associate professor, Agronomy Department, UF/IFAS Range Cattle Research and Education Center; UF/IFAS Extension, Gainesville, FL 32611.

The use of trade names in this publication is solely for the purpose of providing specific information. UF/IFAS does not guarantee or warranty the products named, and references to them in this publication do not signify our approval to the exclusion of other products of suitable composition. All chemicals should be used in accordance with directions on the manufacturer's label.

The Institute of Food and Agricultural Sciences (IFAS) is an Equal Opportunity Institution authorized to provide research, educational information and other services

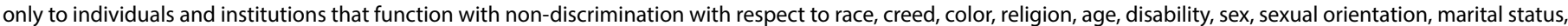

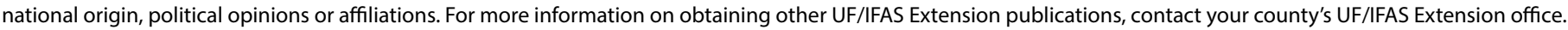
U.S. Department of Agriculture, UF/IFAS Extension Service, University of Florida, IFAS, Florida A \& M University Cooperative Extension Program, and Boards of County Commissioners Cooperating. Nick T. Place, dean for UF/IFAS Extension. 
are easily spread when mechanical controls such as hand weeding are employed. The seed pods will dehisce readily, even from spraying operations.

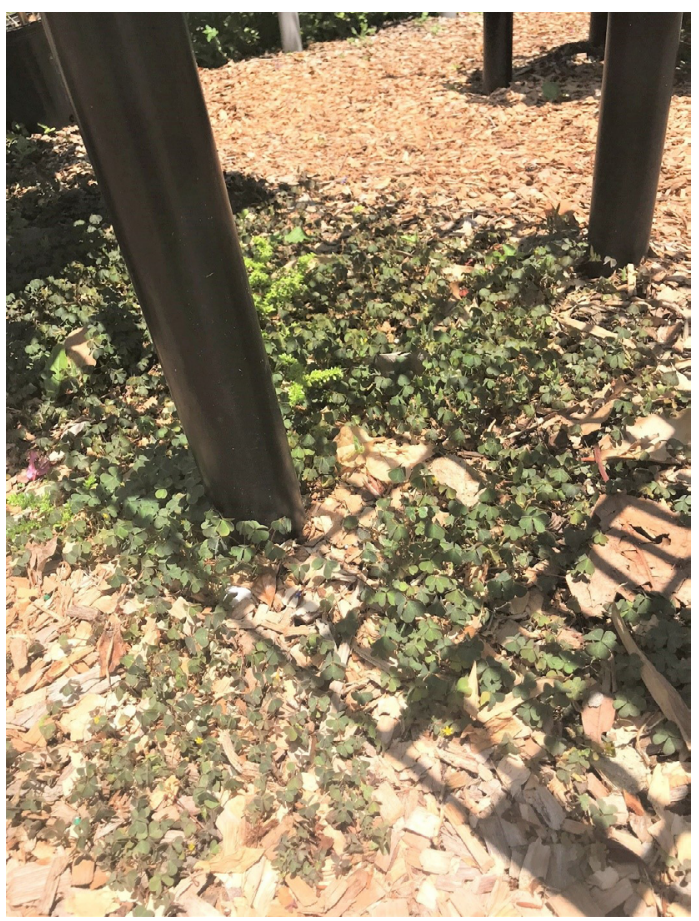

Figure 1. Creeping wood sorrel growing under nursery benches. Credits: Ramdas Kanissery, UF/IFAS

Hairy bittercress (Cardamine hirsuta): An annual or biennial broadleaf weed of the Brassicaceae (mustard) family, with leaves growing in a basal rosette. The petioles and base of its flowering stalk are hairy.

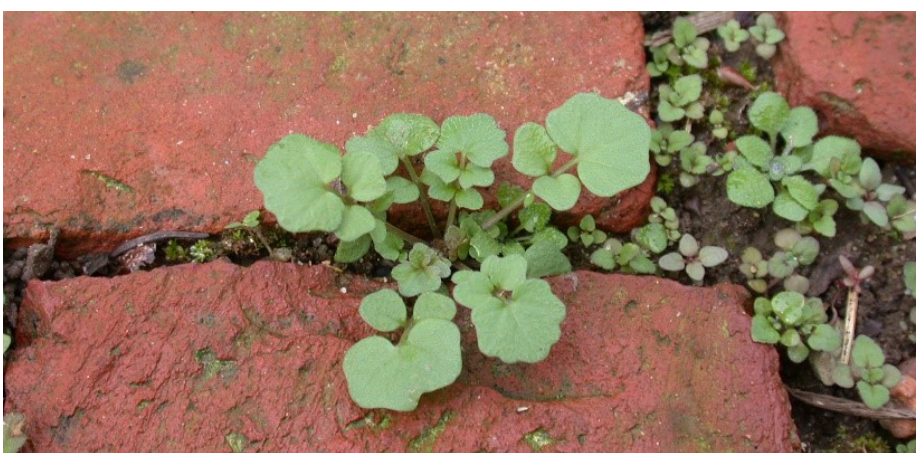

Figure 2. Hairy bittercress.

Credits: Randall G. Prostak, University of Massachusetts

Prostrate spurge (Euphorbia humistrata): A typically lowgrowing plant of the Euphorbiaceae family, with occasional specimens reaching as high as 30 centimeters. Leaves are oval and elongate, often mottled with a purple hue. The flowers are small with a whitish to pink color. As with other spurges, a distinctive white milky sap will ooze from wounded leaves or broken stems.

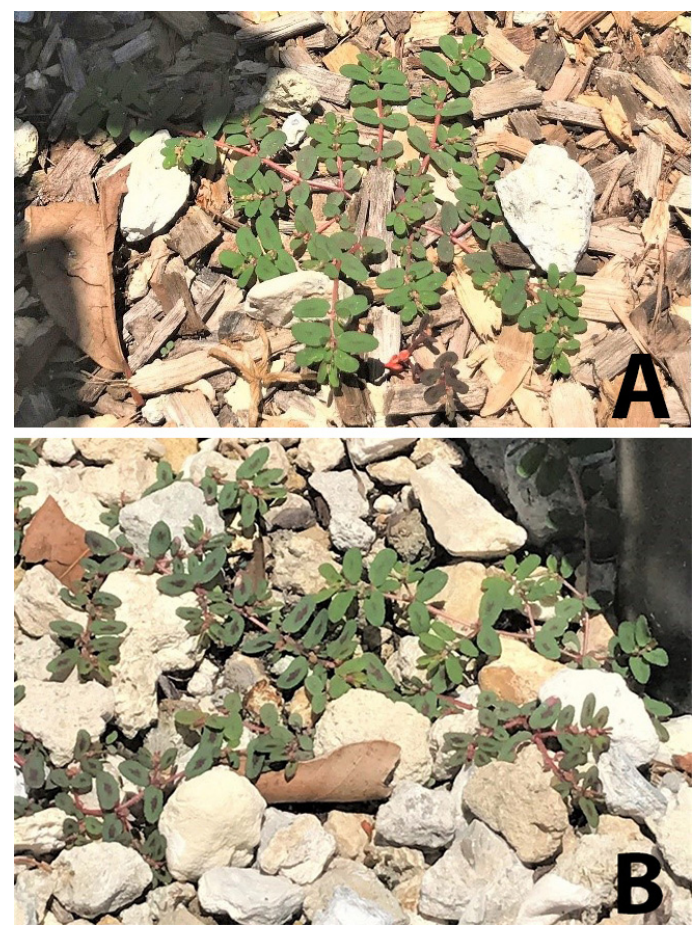

Figure 3. Prostrate spurge growing on nursery floors mulched with wood chips (A); and rock (B).

Credits: Ramdas Kanissery, UF/IFAS

Common chickweed (Stellaria media): An annual flowering plant in the carnation family, Caryophyllaceae. It has weak, sparsely hairy, slender stems with oval and opposite leaves. Lower leaves have petioles. Flowers are small and white with multiple deeply lobed petals.

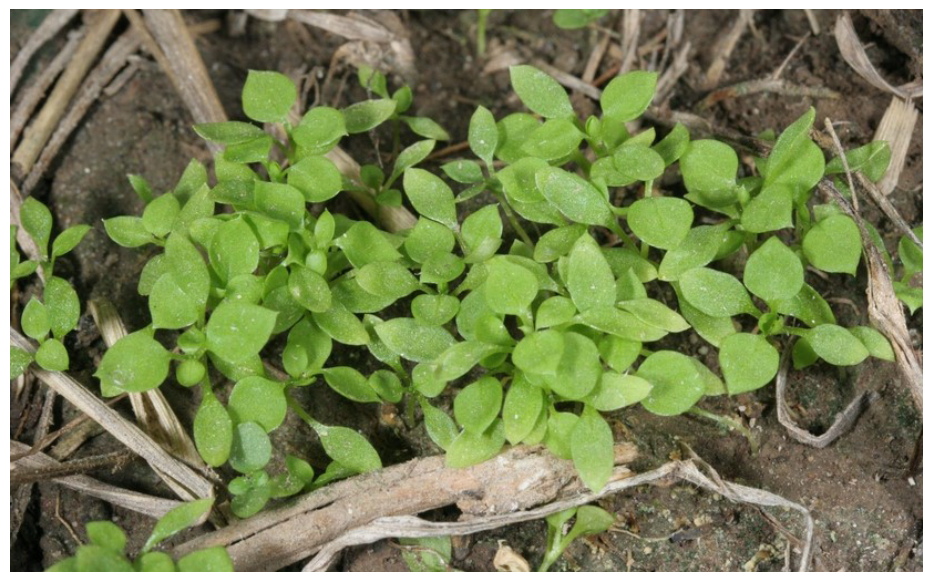

Figure 4. Common chickweed.

Credits: University of Missouri, Division of Plant Sciences

\section{Weed Management in Citrus Nurseries}

To keep nursery stock weed-free, an effective integrated weed management program is important (Singh et al. 1996). Preventive measures, sanitation, mechanical and cultural practices, and the selective use of herbicides come under this approach. 


\section{Prevention and Sanitation}

Prevention and sanitation are the grower's first lines of defense against weeds (Smith 2014). The greenhouse is a controlled environment designed to keep out external disturbances such as weed seeds and propagules that could lead to weed growth. The citrus propagules to be used for rootstock and scion production should be certified and weed-free. However, it is possible that weed seeds could enter the greenhouse through wind, contaminated substrate or seed, equipment, animals, and people. Careful attention to these potential entry routes helps reduce opportunities for weed seeds to get inside the greenhouse.

Greenhouse structures should be inspected regularly to ensure screening is intact and there are no gaps through which windblown seed, as well as insects or other pests, could potentially enter. Weeds and their seeds can also be introduced into the greenhouse on infected plant material, tools, and equipment. Weed seeds and rhizomes may be kept out of the greenhouse by using sterile media, clean plant materials, and clean equipment, and by controlling weeds outside the greenhouse (Smith 2014).

Shipments of plants need to be thoroughly inspected for small weeds or other pests before placing them inside the greenhouse. Walkways and alleys leading to the greenhouse entrance should be kept free of any vegetation. Areas under benches ought to be clean; do not allow plant debris or potting media to collect. When compared with bare soil or gravel alone, which can be easily contaminated, concrete floors or gravel covered with weed barrier fabric are more effective at preventing weed germination and have the benefit of being easy to maintain. Containers should be thoroughly washed and disinfected with pressurized water and chemical disinfectants to remove weed seeds, dirt, and pathogens if they are to be reused (Marble and Pickens 2015).

All nursery areas should be regularly scouted for weeds. While scouting, the type of weeds (broadleaf, sedge, or grass), life cycle (annual, biennial, or perennial), and location should be noted. Weeds should be removed from pots, floors, and benches before they flower and produce seed. For example, a single bittercress plant can produce about 5,000 seeds, which can be propelled more than 9 feet from the plant and germinate in as few as 5 days! Weeds like creeping wood sorrel also expel seeds by force throughout a greenhouse (Smith 2014).

\section{Mechanical Measures}

Continuous scouting and removal are critical to prevent flowering and seed production. Weeds left on the greenhouse floor could reroot, and seeds left on these could still sprout and contaminate the greenhouse. Even pulled weeds can continue to set flower and produce new seeds under suitable greenhouse conditions (Marble and Pickens 2015). Mechanical means of weed control can be an expensive practice and can cause injuries to the root and trunk of citrus seedlings, leaving them vulnerable to diseases. The narrow rows and height of nursery stock limit the use of machinery for weed management (Singh et al. 1996). The following mechanical measures can be employed for weed management in greenhouse nurseries.

\section{HAND PULLING}

Any escaped weeds can be manually removed before they produce seed. Pulling should be done carefully to avoid damaging the crop. When new shoots are subject to breakage, manual control should be delayed until the shoots are mature (Neto et al. 2015).

\section{PHYSICAL BARRIERS}

Physical barriers such as weed block fabric help limit weed establishment on greenhouse floors. The weed fabric should be left bare for easy cleaning. Covering the weed fabric with gravel is not suggested since it makes removal of spilled media and crop debris difficult. Any tears in the weed block fabric should be immediately repaired.

\section{Cultural Control Practices}

Wet environments in the greenhouse allow algae, moss, and ferns to proliferate. Overwatering provides conducive conditions for weeds and crop pathogens, which can grow over and cover surfaces of concrete, gravel, benches, floors, and potting media. Standing water and algae may pose a safety threat for workers due to slippery surfaces.

Overwatering and overfertilizing crops should be avoided, and irrigation equipment should be maintained to ensure efficient and uniform applications. Ensuring adequate drainage and floor slope will minimize standing water. Using coarse gravel and re-covering gravel floors that have become choked with potting media and other crop debris also helps to reduce moisture. Concrete floors must be engineered to allow water to drain from the greenhouse. Increasing ventilation and spacing plants properly also helps reduce humidity and subsequent weed seed germination. Disinfectants may be used to control algae, moss, and ferns (Marble and Pickens 2015). 


\section{Chemical Weed Control}

There are a limited number of herbicides labeled for use inside greenhouses because of the potential for crop injury from volatilization or spray drift. Spray drift is more likely if fans are operating during the time of application. Herbicides should be used as the last resort for weeds not effectively controlled using the methods mentioned above. Herbicide vapors can be easily trapped within an enclosed greenhouse and injure nursery foliage. Before use, ensure that the herbicide selected is labeled for use in greenhouses. All label instructions and precautions must be carefully followed. A dedicated sprayer, clearly labeled for herbicide use only, must be used (Smith 2014).

Herbicides are broadly classified according to their mechanism of action (contact or systemic) and manner in which they are used (pre-emergent or post-emergent). Use of pre-emergent herbicides in the greenhouse is not generally recommended, because they can continue to vaporize for a considerable time after application, causing crop damage, and because they can persist for up to a year (Smith 2014). Indaziflam (Marengo ${ }^{\circledR}$ ) is the single pre-emergent herbicide labeled for use inside greenhouses and other enclosed structures. Marengo ${ }^{\circ}$ has residual activities when applied to greenhouse floors when there are no plants in the greenhouse. Greenhouses should be ventilated for up to 24 hours after application prior to placing plants back inside. Marengo ${ }^{\circ}$ can also be tank-mixed with a variety of post-emergent herbicides to control existing weeds.

Most herbicides labeled for use inside greenhouses are post-emergent herbicides that control weeds after they germinate. Post-emergent herbicides work best when weeds are small and actively growing (Marble and Pickens 2015). There are several post-emergent herbicides that can be used under greenhouse benches and on the floors. It is important to note that contact herbicides kill only the parts of plants contacted by the herbicide, so thorough spray coverage is needed for these to be effective. On the other hand, systemic herbicides are absorbed and move through the plant. Systemic herbicides work best when applied to actively growing weeds when the temperature is above $50^{\circ} \mathrm{F}$. Care should be taken that systemic herbicides do not come in contact with nursery foliage. The best times to apply herbicides to control existing weeds while avoiding potential crop damage are those when the greenhouse is empty, such as periods before, in between, or after crop cycles. Irrigating seedlings too soon after applying an herbicide can wash it off the target weeds under the benches and reduce its effectiveness (Smith 2014). When using herbicides (or any other pesticide), manufacturer's label recommendations must always be followed to achieve optimal weed control and avoid crop injury (Marble and Pickens 2015). Table 1 displays details of chemical herbicides that can be used inside greenhouses and summarizes application suggestions for herbicides in citrus nurseries and greenhouses.

\section{NATURAL-BASED HERBICIDES}

In addition to chemical herbicides, there are a few bioherbicides that can be used by nursery growers. Some of these include acetic acid, citric acid, citrus oil, and clove oil (eugenol). These are post-emergent, nonselective, contact herbicides that work by disrupting the cell membranes and desiccating the plants. These herbicides are most effective on weeds in their early growth stage. Multiple applications are necessary for perennial or reemerging weeds (Smith 2014).

\section{Managing Weeds outside the Greenhouse Nursery}

Managing weeds outside the greenhouse nursery is crucial to prevent weed seeds from entering the greenhouse. Weeds creeping and growing under the greenhouse foundation may host insects and pathogens. Generally, a 20 -foot weed-free zone around the greenhouse is recommended. A geotextile fabric may be employed to prevent weed growth outside of the greenhouse. Regular mowing of the surrounding area helps limit weed seeds blowing into the greenhouse.

Chemical control could also be used outside the greenhouse, with an herbicide labeled for such use. Before applying herbicides in the surrounding areas, ensure that the greenhouse is sealed to prevent drift. Choose an herbicide with low volatility. Any auxin-type herbicides should not be used near greenhouses because of their volatility and the extreme sensitivity of citrus seedlings (Smith 2014).

\section{Acknowledgments}

The authors would like to thank Robert Riefer, Shea Teems, and Aaron Himrod for valuable suggestions during the preparation of the manuscript.

\section{References}

Bureau of Citrus Budwood Registration. 2014. Citrus Nursery Stock Certification Manual. Division of Plant 
Industry. Florida Department of Agriculture and Consumer

Services. https://www.flrules.org/gateway/ChapterHome.

asp?Chapter $=5 \mathrm{~B}-62$

Marble, C., and J. Pickens. 2015. Weed Control for Orna-

mentals inside Greenhouses and Other Enclosed Structures.

ENH1267. Gainesville: University of Florida Institute of

Food and Agricultural Sciences. https://edis.ifas.ufl.edu/

ep528

Neto, H. B., S. R. d. Silva, F. d. A. A. M. Filho, M. B.

Sposito, and M. M. Caputo. 2015. The Citrus Nursery

Practices in Brazil. Vivecitrus Oroganização Paulista de

Viveiros de Mudas Cítricas. https://www.researchgate.net/

publication/316250188_The_Citrus_Nursery_Practices

Singh, C. M., N. N. Angiras, and S. Kumar. 1996. Weed

Management. M D Publications Pvt. Ltd, New Delhi.

Smith, T. 2014. Managing Weeds in and Around

the Greenhouse. University of Massachusetts

Amherst. https://ag.umass.edu/fact-sheets/

managing-weeds-in-around-greenhouse 


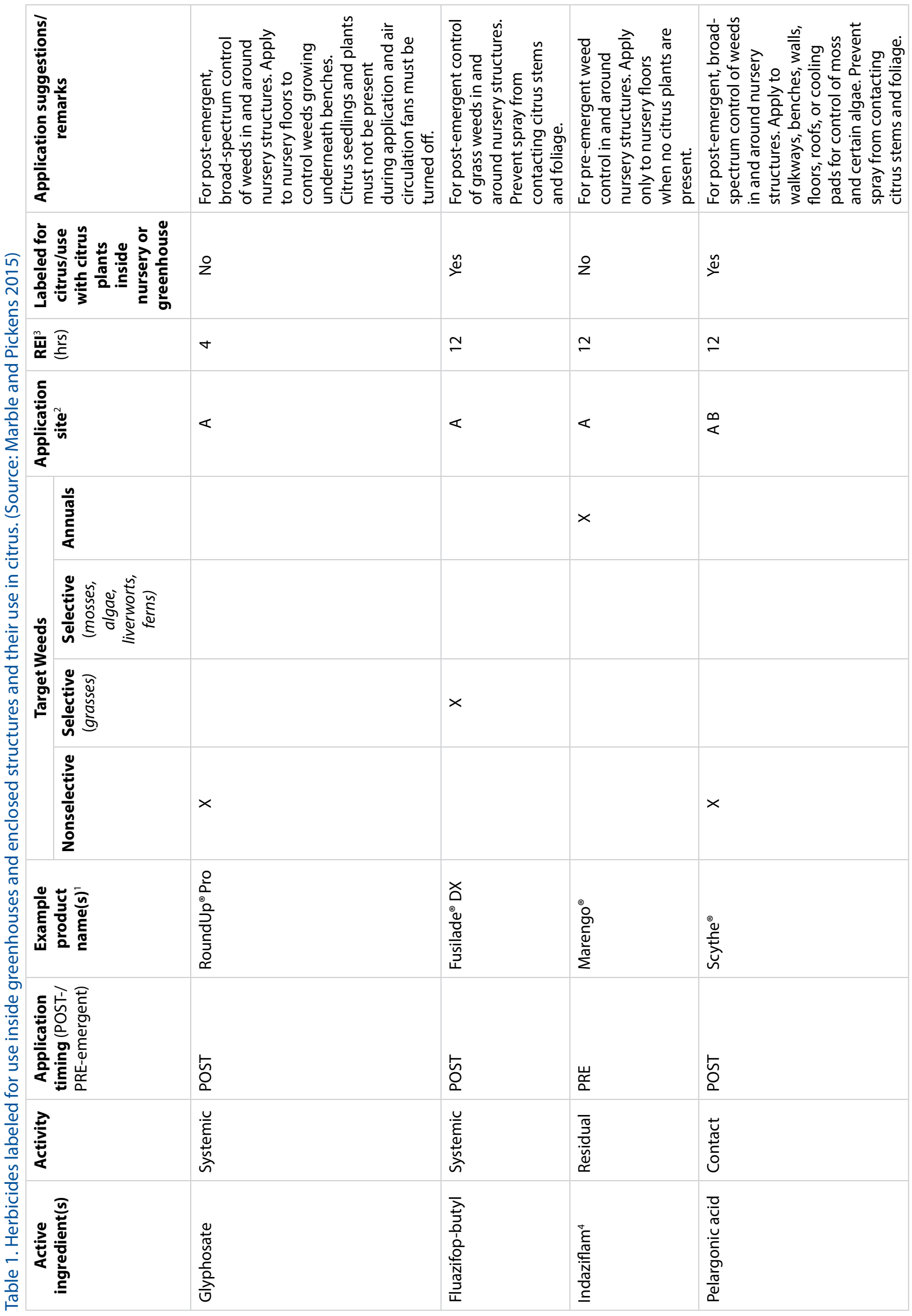




\begin{tabular}{|c|c|c|c|}
\hline 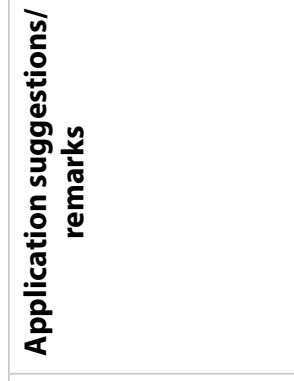 & 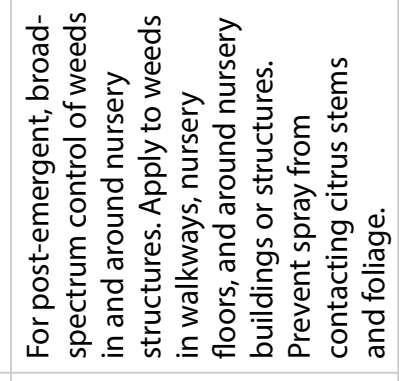 & 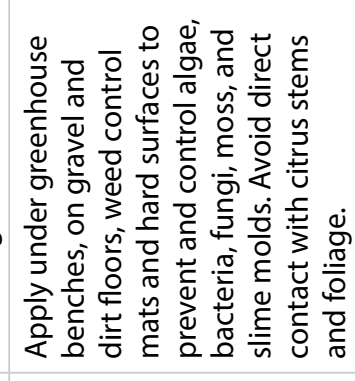 & 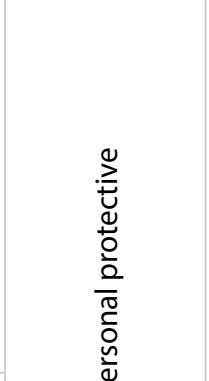 \\
\hline 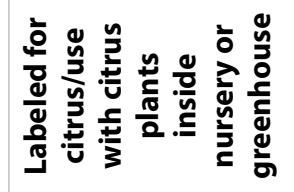 & 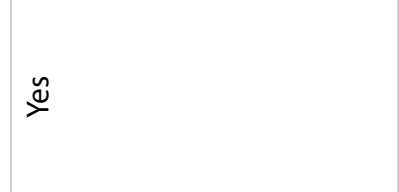 & $\stackrel{\check{\Perp}}{\check{1}}$ & 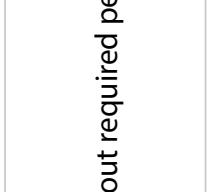 \\
\hline 喛 & d & 0 & 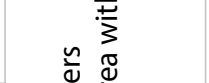 \\
\hline 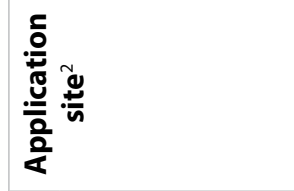 & $\ll$ & $\begin{array}{l}u \\
\infty \\
\ll\end{array}$ & 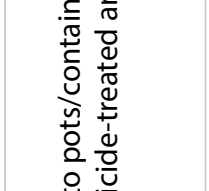 \\
\hline 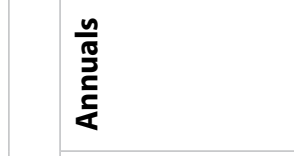 & & & 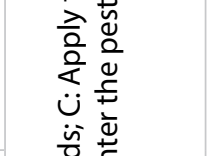 \\
\hline 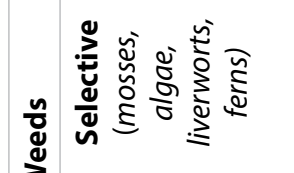 & & $\times$ & 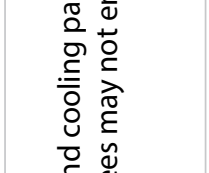 \\
\hline 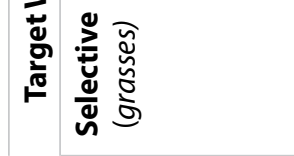 & & & 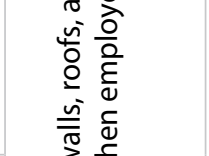 \\
\hline 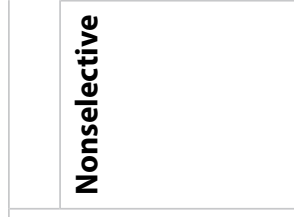 & $\times$ & & 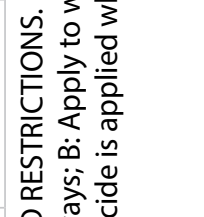 \\
\hline 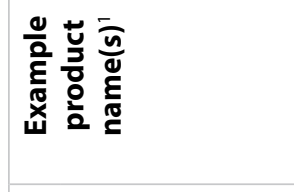 & $\begin{array}{l}\ddot{x} \\
\frac{x}{x}\end{array}$ & 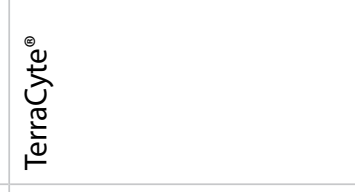 & 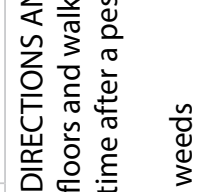 \\
\hline 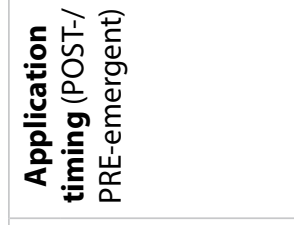 & 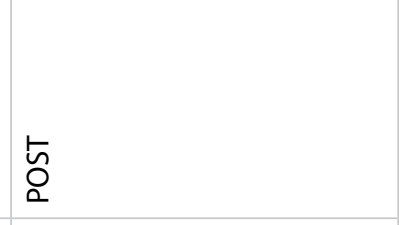 & 氖 & 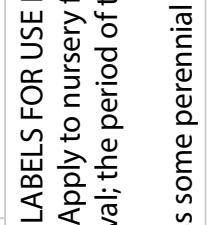 \\
\hline$\sum_{\vec{E}}^{\vec{z}}$ & $\begin{array}{l}\breve{T} \\
\stackrel{\tilde{D}}{0} \\
0\end{array}$ & $\begin{array}{l}\breve{t} \\
\stackrel{\tilde{T}}{0} \\
0\end{array}$ & 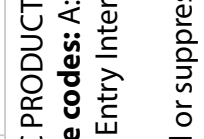 \\
\hline 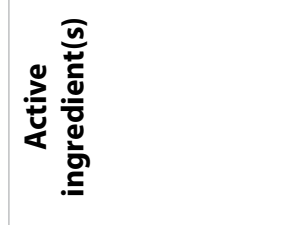 & 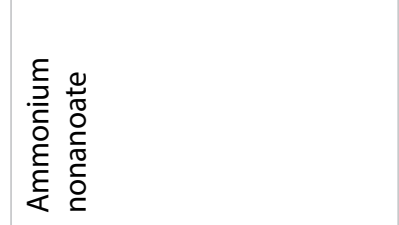 & 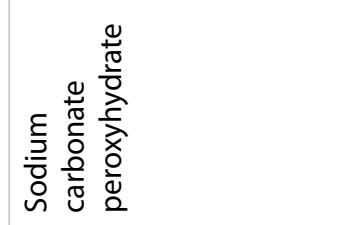 & 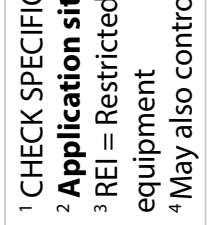 \\
\hline
\end{tabular}

